\title{
SLC3A1 Gene
}

National Cancer Institute

\section{Source}

National Cancer Institute. SLC3A1 Gene. NCI Thesaurus. Code C94688.

This gene is involved in the transport of amino acids. 